УДК 655.226.6

\title{
ДРУКУВАЛЬНІ ВЛАСТИВОСТІ ОФСЕТНИХ ФОРМ
}

\author{
๑) В. М. Скиба, аспірант, НТУУ «КПI», Київ, Україна
}

\begin{abstract}
Проведено исследование влияния процесса печати на печатно-технические свойства элементов печатной формы монометаллических форм плоской офсетной печати с увлажнением.
\end{abstract}

\section{Was explored impact of the printing process on printing- technical properties of the printing and non-printing elements on the offset printing plates.}

\section{Постановка проблеми}

Друкарсько-технічні властивості друкарської форми характеризуються поточним станом друкувальних та проміжних елементів, які змінють свої властивості під впливом параметрів друкарського контакту. Важливим показником друкарськотехнічних властивостей $є$ коефіцієнти фарбосприйняття і фарбоперенесення, які характеризують процеси насичення фарбою друкувальних елементів та її подальшу передачу у системі «друкарська форма-офсетне гумовотканинне полотнище». А якісне формування зображення на друкарській формі забезпечується стабільністю процесу зволоження поверхні проміжних елементів.

Показники фарбосприйняття та фарбоперенесення друкарської форми залежать від умов експлуатації, реологічних властивостей фарби, ступеня спрацювання і поточних властивостей друкувальних елементів. Процес зволоження характеризується здатністю поверхні проміжного елементу утримувати необхідну кількість зволожувального роз- чину протягом процесу друкування. Оптимальні показники вище вказаних параметрів визначають стабільність формування зображення на друкарській формі, що безпосередньо визначає кінцеву якість відбитка.

Саме тому дослідження зміни друкарсько-технічних властивостей елементів друкарської форми під впливом процесу друкування $€$ надзвичайно актуальним та дозволить визначити подальші напрямки стабілізації процесу друкування у плоскому офсетному друці зі зволоженням.

\section{Аналіз попередніх досліджень}

Практично відсутні дані щодо друкарсько-технічних властивостей сучасних формних матеріалів і форм плоского офсетного друку. В роботах [1-3] вивчалися адсорбційні властивості, морфологія поверхні та властивості поверхневої фази проміжних елементів друкарських форм. В роботі [4] досліджувалися поверхневі явища на друкарських формах офсетного плоского друку та виявлено вплив концентрації іонів кальцію на електростатичне 


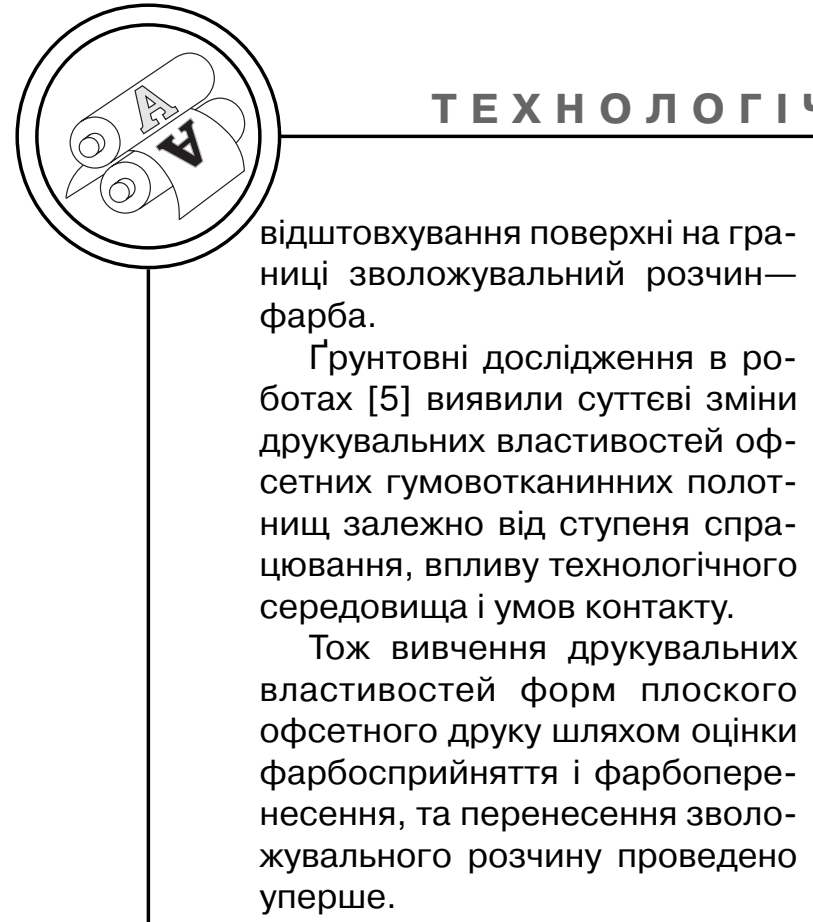

\section{Мета роботи}

Проведення дослідження впливу параметрів процесу друкування на зміну друкарсько-технічних властивостей елементів монометалевих друкарських форм плоского офсетного друку зі зволоженням залежно від накладу.

\section{Результати проведених досліджень}

Для дослідження були обрані сучасні формні матеріали, а саме: фотополімеризаційноздатні пластини FUJIFILM Brillia LP-NV. Друкування накладу відбувалося на машині плоского офсетного друку зі зволоженням КВА Rapida 105 тріадними фарбами Huber Corona на картоні Alaska GC2 масою 250 г/м², із застосуванням 10 \% спиртового зволожувального розчину із добавкою Acedin 1991 - 3,0 \%. Наклад досліджуваних друкарських форм склав 70,0 тис. аркушів, швидкість друкування 10,0 тис. арк./год.

Моделювання офсетного плоского друку проводилося на прободрукарському пристрої ЛП-1 у лабораторії друкарських процесів Видавничо-поліграфічного інституту НТУу «КП|». Режими друкарського контакту були такими: швидкість $2,5 \mathrm{~m} / \mathrm{c}$, тиск 1,1 МПа. Для проведення моделювання друкарського процесу застосовувалися такі матеріали: офсетна друкарська фарба Huber Corona, зволожувальний розчин на основі концентрату Acedin 1991, папір Mango Satin масою 90 г/ $\mathrm{M}^{2}$ та Lumi Art масою 250 г/м², друкарська форма FUJIFILM Brillia LP-NV, офсетне гумовотканинне полотнище $\mathrm{Ad}$ vantage New (Sava, Словенія). Для вимірювання оптичної густини відбитків було застосовано денситометр Gretag Macbeth QuikDens 200.

Накочування фарби на форму відбувалося впродовж 1 хв. Зважування зразків проводилося на кожній стадії процесу дослідження. Для прямого друку визначали вагу друкарської форми: до процесу нанесення зволожувального розчину, зі зволожувальним розчином, з фарбою та зволожувальним розчином до та після друку; для друку з переконтактом додатково вагу офсетної форми до та після процесу друкування. Коефіцієнти фарбосприйняття та фарбоперенесення визначали за методикою [6].

Як видно з рис. 1, загальна закономірність зміни коефіцієнта фарбосприйняття $\mathrm{K}_{n}^{\circ \Phi}$ друкарської форми зумовлена шорсткістю її поверхні, що узгоджується з характером її мікрогеометрії. Загалом, при товщині шарів на вихідній формі приладу ЛП-1, яку можна умовно ототож- 
нити з накатною системою, товщина шарів коливається в межах 1,8-5,0 мкм і за цих умов $\mathrm{K}_{\mathrm{n}}^{\text {ОФ }}$ має тенденцію до зменшення від 25 до $20 \%$, як доведено в роботах $[5,7,8]$, фарбосприйняття залежить від того, яку кількість фарби необхідно нанести для повного насичення поверхні. Чим шорсткіша поверхня, тим більше фарби потрібно для повного її покриття, але є оптимальний шар, що забезпечує максимальний перехід.

Як видно із рис. 1, тут відсутня різко виражена ділянка екстремуму. Тож можна констатувати, що у встановлених межах товщини вихідного шару фарба буде переходити на поверхню друкувальних елементів в тій пропорції, скільки це необхідно для їх насичення. А оскільки шорсткість не висока, то і $\mathrm{K}_{n}^{\text {OФ }}$ не має високих значень. Тобто тільки третина вихідного фарбового шару буде переходити на друкарську форму.

Щодо друкарських форм, котрі були у друкарському контакті, то різниця фарбосприйняття незначна, але все таки, є тенденція до зниження величини $\mathrm{K}_{\mathrm{n}}^{\text {ОФ, }}$, що коливається в межах від 23 до 14 \% при збереженні загального характеру кривої $\mathrm{K}_{\mathrm{n}}^{\text {OФ }=}$ $=f\left(h_{\phi}\right)$ (див. рис. 1, крива 2). Це також узгоджується із зміною шорсткості поверхні друкарської форми, оскільки шорсткість зменшується в результаті дру-

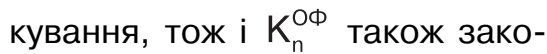
номірно зменшується, оскільки насичення друкарської форми відбувається за менших кількостях фарби.

Аналіз коефіцієнта фарбоперенесення $\mathrm{K}_{\mathrm{n}(\phi)} 3$ друкарської форми на папір теж виявив загальні закономірності. Практич-

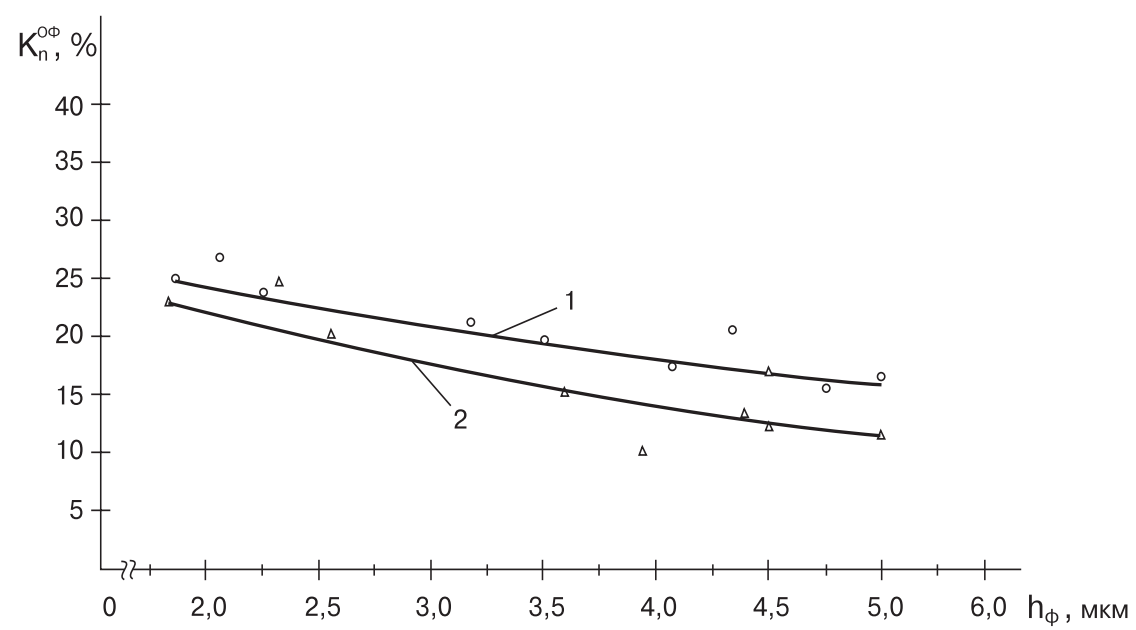

Рис. 1. Коефіцієнт фарбосприйняття друкарської форми в умовах друкарського контакту «циліндрична форма-офсетна форма», тиск 1,1 МПа; швидкість 2,5 м/с: 1 - друкарська форма до друку; 2 - друкарська форма після 70,0 тис. відбитків 


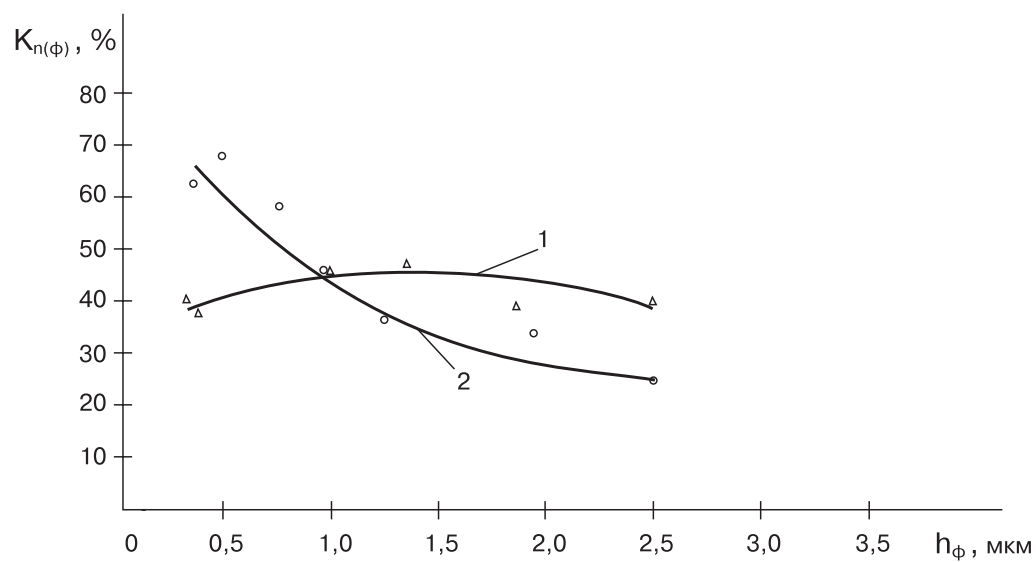

Рис. 2. Залежність коефіцієнта фарбоперенесення з друкарської форми на папір при тиску 1,1 МПа; швидкість 2,5 м/с: 1 - папір крейдований; 2 - папір офсетний

но, ступінь спрацювання друкарської форми не впливає на фарбоперенесення. Для паперу офсетного в межах 37-41\% фарби переходить на папір за одних і тих самих умов контакту (див. рис. 2, крива 2). Для крейдованого паперу фарбоперенесення носить більш екстремальний характер, що узгоджується із загально відомими дослідженнями [8] і пояс- нюється як для офсетного, так і для крейдованого, шорсткістю паперу, яка під дією параметрів друку зазнає стиску.

Отже, спрацювання друкувальних елементів, зменшення адгезійного шару фарби, який завжди присутній для забезпечення умов фарбоперенесення підтверджується і результатами робіт $[5,7]$, де було виявлено зміни фарбоперенесення оф-

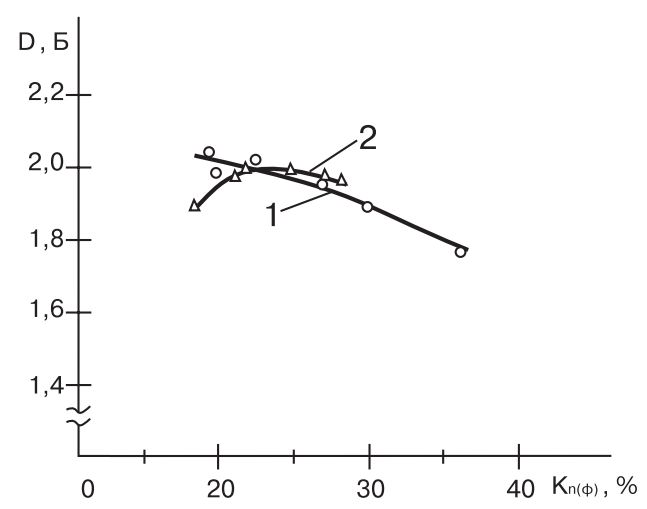

Рис. 3. Залежність величини оптичної густини відбитка від коефіцієнта фарбоперенесення: 1 - друкарська форма до друку; 2 - друкарська форма після 70,0 тис. відбитків 


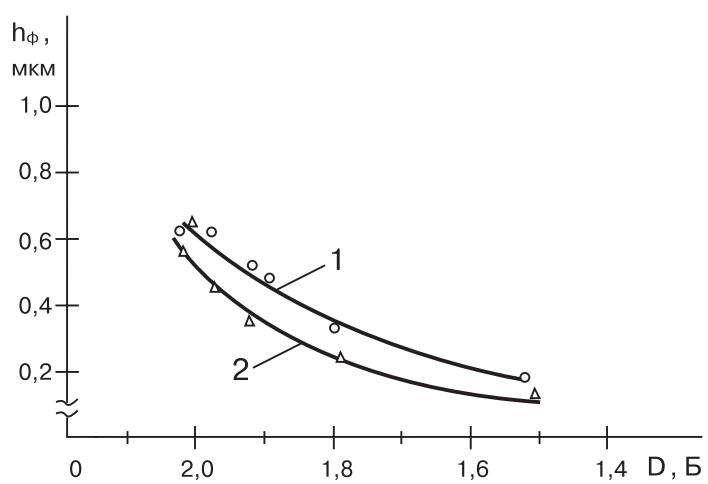

Рис. 4. Залежність величини оптичної густини від товщини фарбових шарів: 1 - друкарська форма до друку; 2 - друкарська форма після 70,0 тис. відбитків

сетного гумовотканинного полотнища в результаті спрацювання.

Однак, як видно із рис. 3, оптична густина відбитків, незалежно від характеру фарбоперенесення для нових і спрацьованих форм, незмінно висока і характеризує закономірну тенденцію зниження величини залежно від зниження товщини фарбових шарів на відбитках (рис. 4), що випливає із самого визначення оптичної густини як фізичної величини, залежної від концентрації і товщини шарів.

Для зволожувального розчину також закономірним виявився залишковий значний шар, що не всотується у папір при вивченні нових друкарських форм у порівнянні із спрацьованими.

Як видно із рис. 5, для нових проміжних елементів мінімаль-

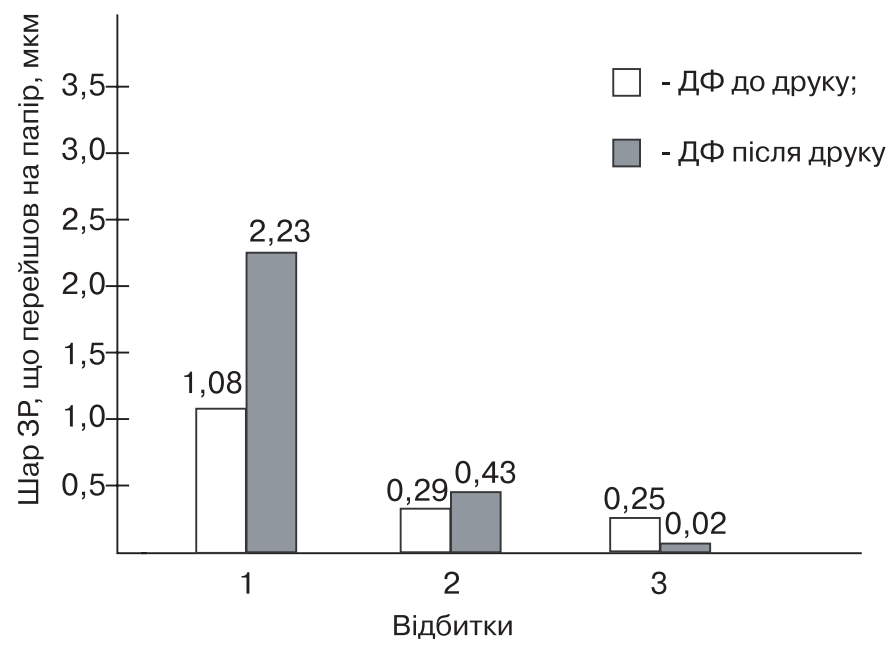

Рис. 5. Перенесення зволожувального розчину з друкарської форми на папір офсетний 
ний шар, що утримується, складає 0,25 мкм, а для проміжних елементів після 70,0 тис. відбитків цей шар складає лише 0,02 мкм. Тобто спрацьована форма зволожується значно більше і віддає вологи також більше, ніж нова. Це пояснюється явищами, що зумовлені змінами пористості, мікрогеометрії поверхні, складу проміжних елементів під впливом факторів друкарського контакту.

\section{Висновки}

1. Вперше проведено визначення фарбосприйняття і фарбоперенесення друкувальних елементів, та перенесення зволожувального розчину проміжни- ми елементами сучасних формних матеріалів плоского офсетного друку і форм на їх основі.

2. Встановлено вплив спрацювання друкувальних елементів сучасних монометалевих друкарських форм плоского офсетного друку на характер фарбосприйняття і фарбоперенесення друкарської фарби залежно від паперу та товщини шарів на контактувальних парах.

3. Визначено характер перенесення зволожувального розчину та встановлено мінімальний шар, що утримується проміжними елементами друкарських форм залежно від ступеню спрацювання друкарських форм.

1. Сулакова Л. Физико-химические исследования современных предварительно очувствленных пластин / Л. Сулакова, С. Новиков, О. Корункова // Полиграфия. - 1998. - № 3. - С. 72-74. 2. Сулакова Л. Физико-химические исследования современных предварительно очувствленных пластин / Л. Сулакова, С. Новиков, О. Корункова // Полиграфия. - 1998. № 4. - С. 88-90. 3. Сулакова Л. Условия гидрофильности пробельных элементов офсетных печатных форм / Л. Сулакова, С. Новиков, О. Корункова // Полиграфия. - 1999. - № 5 - С. 59-61. 4. Трауцеддел Р. Поверхневі явища на формах офсетного друку / Р. Трауцеддел, К. Вольф // Технологія і техніка друкарства. - 2003. - № 1. - С. 42-45. 5. Зоренко О. В. Декелі в друкарському процесі : Монографія / О. В. Зоренко, О. Ф. Розум. К. : Видавничо-поліграфічний центр «Київський університет», 2008. - 168 с. 6. Величко О. М. Практикум із загального та поліграфічного виробництва / О. М. Величко, О. В. Зоренко, І. О. Кириченко. - К. : НТУУ «КПІ», 2006. 152 с. 7. Величко О. М. Опрацювання інформаційного потоку взаємодією елементів друкарського контакту : Монографія / Олена Михайлівна Величко - К. : Видавничо-поліграфічний центр «Київський політехнік», 2005. 264 c. 8. Jakucewicz S. Bledy w drukowaniu offsetowym a wady papieru: monografia. - Warszawa : Adamantan, 2010. - $160 \mathrm{~s}$. 